\title{
Kerupuk Kulit Ikan Pari Sebagai Alternatif Peningkatan Pendapatan Rumah Tangga Di Karundang Kota Serang
}

\author{
Deni Sunaryo \\ Jurusan Manajemen, Universitas Serang Raya \\ Email: denisunaryomm@gmail.com
}

\begin{abstract}
Abstrak
Potensi keluarahan Karundang Kecamatan Cipocok Jaya Kota Serang salah satunya adalah pengolahan ikan pari, dimana pengolahan ikan pari ini hanya diambil dagingnya saja sedangkan kulit ikan pari dan tulang ikan pari dijadikan limbah. Nilai gizi dari limbah ikan pari sangatlah besar sehingga mampu menjadikan peluang untuk mengoptimalkan nilai tambah dari limbah tersebut menjadi nilai guna dan nilai tambah baik bagi warga maupun bagi lingkungan sekitarnya. Program pengabdian yang dilakukan pada tanggal 15 Maret 2019 bertempat di salah satu Posko kegiatan warga Kelurahan Karundang kecamatan Cipocok Jaya Kota Serang. Jumlah peserta yang mengikuti kegiatan ini sebanyak 16 orang warga setempat. Proses pelatihan ini dilakukan dengan cara pengenalan bahan baku kulit ikan pari yang masih segar (belum busuk), bersifat liat atau tidak mudah robek, memiliki ketebalan minimal 0,5 mm (sebelah sisik dibersihkan), kuat dan tidak mudah hancur. Serta bahan baku pengolahan untuk memasaknya dan pengemasan yang sederhana. Dalam kegiatan ini pengabdi meminta informasi berkaitan dengan kegiatan pengabdian pengolah kulit ikan pari menjadi kerupuk baik dari sisi kegiatan maupun pemateri dalam mengarakan kegiatan. Program pengabdian ini disambut warga dengan antusias dan respek terhadap kegiatan ini serta memberikan saran untuk kegiatan pengabdian selanjutnya yaitu membuat abon dari kulit ikan pari.
\end{abstract}

Kata Kunci: Limbah Kulit Ikan Pari, Pendapatan.

\begin{abstract}
One of the potentials of the Karundang sub-district in Cipocok Jaya District, Serang City, is processing stingrays, while the processing of stingrays is only taken from the meat while the skin of stingrays and stingray bones is used as waste. The nutritional value of larger stingray waste so that it is able to produce added value from that value becomes a useful value and added value for both the residents and the surrounding environment. The service program carried out on March 15, 2019, at one of the posts of the Karundang Village community activity in the Cipocok Jaya sub-district, Serang City. The number of participants who participated in this activity were 16 local residents. The training process is carried out by introducing stingray skin raw material that is still fresh (not yet rotten), fire resistant or not easily torn, has a thickness of at least $0.5 \mathrm{~mm}$, left and right easily damaged. As well as simple processing materials for cooking and packaging. In this activity the servant asked for information related to the service activities of the processing of stingray skin into crackers both in terms of activities and presenters in expressing activities.This service program supports residents with enthusiasm and respect for this activity and provides advice for the next service activity, which is making abon from stingray skin.
\end{abstract}

Keywords: stingray skin waste, income. 


\section{PENDAHULUAN}

Karundang adalah salah satu kelurahan yang berada di Kecamatan Cipocok Jaya, Kota Serang, Provinsi Banten, Indonesia. Desa Karundang terletak di pinggir jalan, sarana transportasi yang cukup memadai membuat desa ini mudah di lalui.

Di daerah kelurahan karundang Kota Serang terdapat pengolahan ikan pari, dimana dalam proses pengolahan ikan pari tersebut terdapat limbah kulit pari yang tidak dioptimalkan oleh pengolah ikan pari. Masyarakat sekitar pengolahan ikan pari tersebut sangat terganggu atas pencemaran limbah yang dihasilkan oleh pengolahan limbah ikan pari.

Disekitar area pengolahan ikan pari terdapat ibu rumah tangga yang belum mengoptimalkan waktunya guna menghasilkan nilai tambah pendapatan.

Kandungan ikan terutama ikan pari dapat dilihat pada Tabel 1

Tabel. 1 Kandungan Unsur Gizi pada Beberapa Jenis Ikan

\begin{tabular}{|l|l|c|c|c|c|c|c|c|c|}
\hline \multirow{2}{*}{ No } & Unsur Gizi & \multicolumn{9}{|c|}{ Kadar/100 g bahan } \\
\cline { 3 - 10 } & & $\begin{array}{c}\text { Banden } \\
\mathbf{g}\end{array}$ & Belut & Hiu & Kakap & Lele & Pari & $\begin{array}{c}\text { Kakap } \\
\text { Merah }\end{array}$ & Tengiri*) \\
\hline 1 & Energi (kal) & 123 & 92 & 84 & 86 & 93 & 88 & - & - \\
\hline 2 & Air (g) & 72 & 79 & 78 & 77 & 78,1 & 78,9 & 79,5 & 80,4 \\
\hline 3 & Protein (g) & 20 & 16,7 & 20,2 & 20 & 18,2 & 17,9 & 20,54 & 18,66 \\
\hline 4 & Lemak (g) & 4,8 & 2,8 & 0,4 & 1,7 & 2,2 & 1,8 & 0,36 & 18,66 \\
\hline 5 & $\begin{array}{l}\text { Karbohidrat } \\
\text { (g) }\end{array}$ & 0 & 0 & 0 & 0 & 0 & 0 & 0 & 0 \\
\hline 6 & Mineral (g) & 1,2 & 1,5 & 1,4 & 2,4 & 1,5 & 1,4 & 1,46 & 1,2 \\
\hline 7 & $\begin{array}{l}\text { Kalsium } \\
\text { (mg) }\end{array}$ & 150 & 200 & 208 & 200 & 116 & 162 & - & - \\
\hline 8 & Fosfor mg) & 150 & 200 & 208 & 200 & 116 & 162 & - & - \\
\hline 9 & Besi (mg) & 2 & 1 & 0,9 & 1 & 0,2 & 1 & - & - \\
\hline 10 & $\begin{array}{l}\text { Vitamin A } \\
\text { (mg) }\end{array}$ & 45 & 45 & 45 & 9 & 85 & 55 & - & - \\
\hline 11 & $\begin{array}{l}\text { Vitamin B } \\
\text { (mg) }\end{array}$ & 0,09 & 0,1 & 0,01 & 0,05 & 0,1 & 0,07 & - & - \\
\hline
\end{tabular}

Sumber : Daftar Analisis Bahan Makanan Fak Kedokteran UI, Jakarta, 1992 *) Laboratorium kimia LPTD

Dari kandungan unsur gizi pada beberapa jenis ikan dalam Tabel 1 diatas maka unsur gizi yang paling lengkap dalah ikan pari.

Untuk memperoleh kerupuk kulit ikan yang berkualitas baik, maka beberapa peisyaratan harus dipenuhi, di antaranya:

1. Masih segar(belum busuk).

2. Bersifat liat/tidak mudah robeL
3. Memiliki ketebalan minimal $0,5 \mathrm{~mm}$ (sebelah sisik dibersihkan)

\section{Kuat dan tidak mudah hancur.}

Identifikasi terhadap produk olahan perikanan tradisional yang memiliki nilai tambah diperlukan sebagai salah satu bahan kajian bagi masyarakat yang terkait dengan keinginan penambahan pendapatan. Mengkaji nilai tambah produk olahan perikanan akan menjadi inspirasi untuk mengkaji lebih mendalam mengenai aspek pasar dan pemasaran, diantaranya yang menyangkut optimalisasi produk, selera konsumen dan harga produk. Aspek produksi juga dapat dikaji antara lain mengenai upaya peningkatan nilai tambah produk dan pendapatan warga .

Rumusan pengabdian kepada masyarakat adalah dengan cara melakukan optimalisasi pengolahan kulit ikan pari menjadi kerupuk, dimana masyarakat disekitar pengolahan ikan pari belum mengetahui lebih jauh mengenai manfaat tersebut.

Tujuan dari pengabdian kepada masyarakat di kelurahan karundang ini guna memberikan pelatihan nilai tambah dari pengolahan kulit ikan pari, sehingga mampu meningkatkan nilai tambah pendapatan bagi masyarakat kelurahan karundang Kota Serang.

Nilai Tambah adalah pertambahan nilai yang terjadi karena suatu komoditi mengalami proses pengolahan, pengangkutan dan penyimpanan dalam suatu proses produksi (penggunaan/pemberian input fugsional). Nilai tambah dipengaruhi oleh faktor teknis dan faktor non teknis. Informasi atau keluaran yang diperoleh dari hasil analisis nilai tambah adalah besarnya nilai tambah, rasio nilai tambah, marjin dan balas jasa yang diterima oleh pemilik-pemillk faktor produksi (Hayami 1987). Untuk meningkatkan nilai tambah hasil pengolahan kulit ikan pari, maka dilakukan pengawetan dan atau pengolahan hasil-hasil perikanan. Tujuan pengawetan ikan adalah untuk mempertahankakan ikan selama mung kin dengan menghambat atau menghentikan aktivitas mikroorganisme pembusuk. Hampir semua cara pengawetan akan menyebabkan berubahnya sifat-sifat ikan segar, baik itu dalam 
hal bau, rasa, bentuk ataupun tekstur dagingnya (Rahardi, Kristiawati dan Nazarudin 1996).

Kegiatan pembinaan memiliki Beberapa manfaat seperti yang dikemukakan oleh Noe, Hollenbeck, Gerhart, Wright, yaitu21 :

a. Meningkatkan pengetahuan individu (dalam hal ini adalah pelaku usaha) atas budaya dan para pesaing luar.

b. Membantu individu yang mempunyai keahlian untuk bekerja dengan teknologi baru.

c. Membantu individu untuk memahami bagaimana bekerja secara efektif dalam tim untuk menghasilkan jasa dan produk yang berkualitas.

d. Memastikan bahwa budaya usaha menekankan pada inovasi, kreativitas dan pembelajaran.

e. Menjamin keselamatan dengan memberikan cara-cara baru bagi para individu (pelaku usaha) untuk memberikan kontribusi bagi masyarakat pada saat pekerjaan dan kepentingan mereka berubah atau pada saat keahlian mereka menjadi absolut.

f. Mempersiapkan pelaku usaha untuk dapat menerima dan bekerja secara lebih efektif satu sama lainnya, terutama dengan kaum minoritas dan para wanita

Pengolahan hasil perikanan adalah kegiatan mengolah ikan mentah menjadi ikan siap konsumsi dengan dijadikan beraneka produk makanan baru yang berbahan dasar ikan. Dirjen Perikanan menyebutkan karakteristik dari pengolahan ikan tradisional, antara lain : a. Kemampuan pengetahuan pengolah rendah dengan keterampilan yang diperoleh secara turun-temurun. b. Tingkat sanitasi dan higienis rendah, sesuai dengan keadaan lingkungan di sekitarnya yang umumnya tidak memiliki sarana air bersih. c. Permodalannya sangat lemah. d. Peralatan yang digunakan sangat sederhana. e. Pemasaran produk hanya terbatas pada pasaran lokal. Bertitik tolak dari permasalahan yang ada, maka diperlukan model pengolahan baru yang mampu meningkatkan harga jual dengan diolah menjadi produk makanan siap saji, misal : bakso ikan, nugget ikan, abon ikan, rambak kulit ikan, fillet ikan, krupuk tulang ikan, dana aneka olahan hasil ikan lain yang diolah secara kreatif dan inovatif untuk memunculkan produk baru.

Dengan munculnya inovasi terkait produk olahan hasil perikanan akan semakin menambah variasi hasil olahan ikan yang tentu memberikan pilihan lebih banyak bagi masyarakat selaku konsumen untuk memilih dan menikmati ragam olahan produk dengan bahan dasar ikan. Disisi lain juga akan meningkatkan nilai jual ikan dan hasil laut atau perikanan karena di olah menjadi produk yang lebih modern, praktis, dan higienis.

\section{METODE PELAKSANAAN}

Pada pengabdian ini yang menjadi peserta pelatihan adalah ibu rumah tangga sekitar pengolahan ikan pari di Kelurahan Karundang Kecamatan Cipocok Jaya Kota Serang, pada tanggal 15 Maret 2019 bertempat di salah satu Posko kegiatan warga Kelurahan Karundang Kota Serang.

Tahapan yang dilakukan pada proses pengabdian ini dengan cara memberikan pelatihan serta praktek pengolahan kulit ikan pari sampai dengan pengemasan produk agar awet dan tahan lama.

Proses selanjutnya pada pengabdian ini yaitu dengan mengenalkan beberapa bahan baku, proses pengolahan serta pengemasan produk. Dan analisa yang digunakan adalah dengan cara meminita informasi kepada warga yang mengikuti pelatihan dan praktek pengolahan kulit ikan pari dalam rangka mengetahui dan memahami tata cara pengolahan kulit ikan pari dan memberikan saran untuk inovasi produk pengolahan ikan pari selanjutnya.

\section{HASIL DAN PEMBAHASAN}

Pembuatan kerupuk kulit ikan memerlukan peralatan yang sederhana dan murah, sehingga usaha ini dapat dilakukan sebagai usaha sampingan untuk home industri atau usaha kecil menengah. 
Peserta yang mengikuti pelatihan ini sebanyak 16 warga di sekitar Pengolahan ikan pari di kelurahan karundang kota serang.

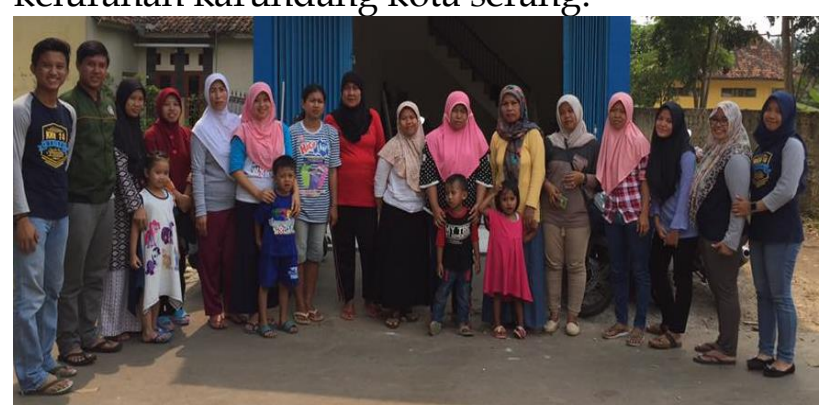

Gambar 1 Peserta Pelatihan pengolahan kerupuk Kulit Ikan Pari di kelurahan

Karundang Kota Serang

Alat-alat tersebut antara lain adalah:

1. Timbangan

2. Gelas ukur atau takaran

3. Gunting atau alat pemotong yaitu untuk memotong bagian-bagian tertentu dari kulit ikan

4. Bak plastik

5.Baskom plastik

6. Penghancur atan blender atau lumping alu

7. Alat penjemur

8. Kompor

9. Seperangkat alat penggoreng

10. Plastik sealer untuk pengemasan

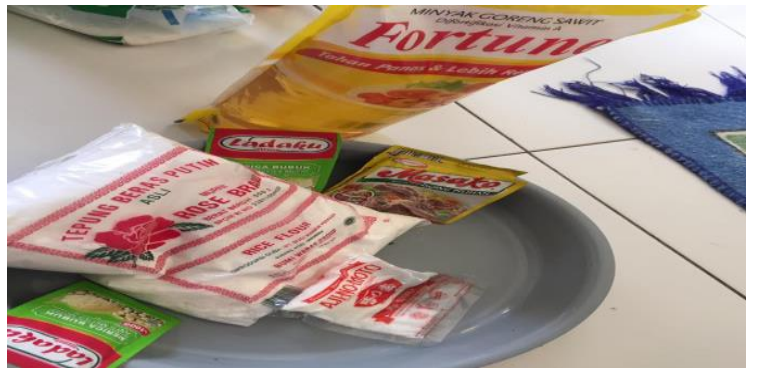

Gambar 2 Bahan Baku Bumbu yang digunakan untuk Pengolahan Kulit Ikan Pari

Cara pembuatan kerupuk kulit ikan terdiri dari beberapa tahapan antara lain:

1) Penyiapan bahan pengeras dan bahan baku

a) Bahan pengeras pada prinsipnya dibuat dengan melarutkan kapur sirih atau batu gamping atau kapur tohor dalam air secara terus menerus selama 7 hari hingah menjadi bubur kabur yang lembut.

b)Bahan baku berupa kulit ikan yang masih kotor, yaitu yang masih bercampur dengan beberapa bagian ikan yang lain (sirip. Ekor, isi perut, duri, atau kepala) harus dipisahkan bagian bagian tersebut dan pilih yang mempunayai kualitas baik. Setelah itu bersihakan dengan air hingga benar-benar bersih dan ditiriskan. Bahan baku dari limbah kulit ikan yang sudah diawetkan sementara atau dikeringkan harus direndam beberapa saat hingga menjadi basah kemudian baru dapat diproses.

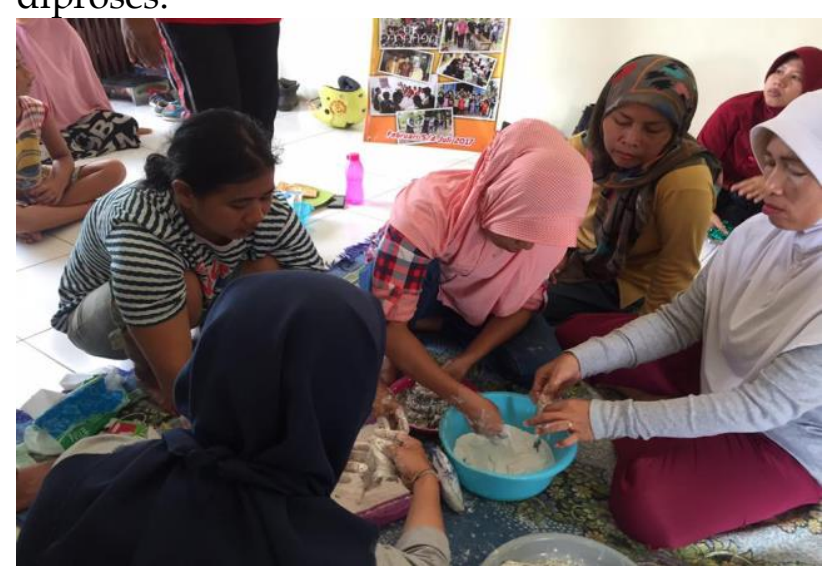

Gambar 3 Proses pengolahan Kulit Ikan Pari menjadi kerupuk

c) Dilakukan proses pengerasan dengan larutan kapur sirih selama 1-2 jam agar kerupuk ikan nantinya memiliki tektur yang kaku renyah dan tidak mudah lembek. Untuk 10 liter air perendaman dibutuhkan 10 sedok air kapur sirih.

d) Setelah proses perendaman kulit ikan dicuci kembali dengan air hingga bau kapur yang menepel pada kulit ikan benar-benar hilang, dan tiriskan.

e) Setelah ditiriskan kulit ikan yang telah keras tersebut dikeringkan. Kulit ikan telah keringkan ini siap diolah

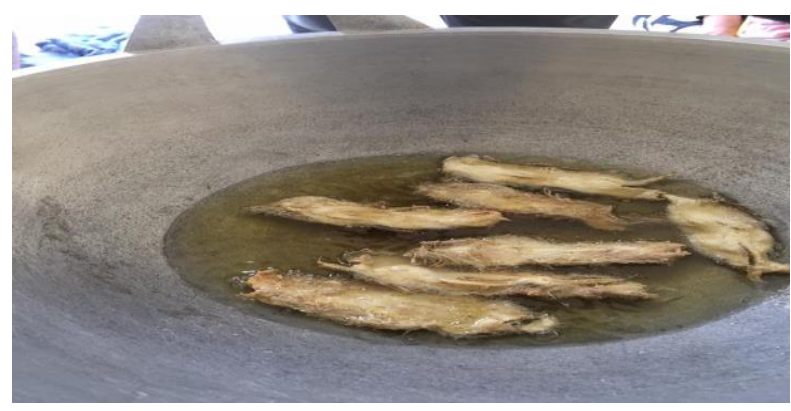

Gambar 4 Proses penggorengan Kerupuk Kulit Ikan Pari

2)Tahapan pengolahan

$45 \mid \mathrm{K}$ a i b o n A b h in a y a 
a. Kulit ikan yang telah kering dipotong dengan gunting untuk menyeragamkan bentuk dan ukurannya, sekaligus untuk memisahkan bagian-bagian lain dari ikan yang mungkin masih terikut misalnya sirip, ekor, duri dan lain-lain.

b.Selajutnya direndam dalam larutan bumbu selama 5- 10 menit kemudian diangkat dan tiriskan.

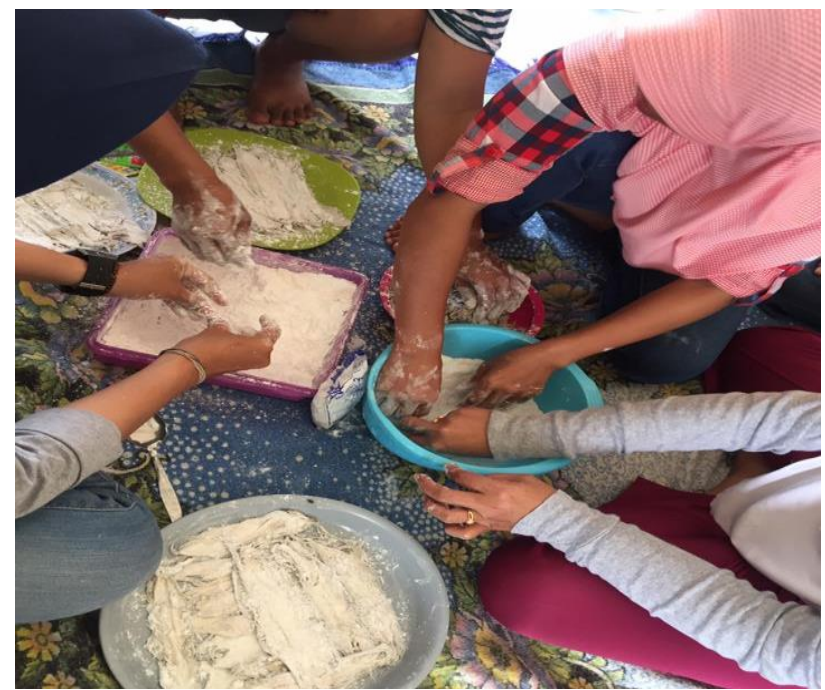

Gambar 5 Proses Peracikan Bumbu

c.Kulit ikan yang sudah dibumbui dijemur hingga benar benar kering. Pada waktu penjemuran sebaiknya di bolak-balik supaya keringnya bena-benar merata. Setelah kering dapat langsung digoreng atau disimpan dalam kantong plastik.

Untuk kemasaan para peserta belum mempunyai ide untuk logo dan merk dagang, pada pelatihan ini hanya sampai pada pengemasan ke dalam plastik biasa.

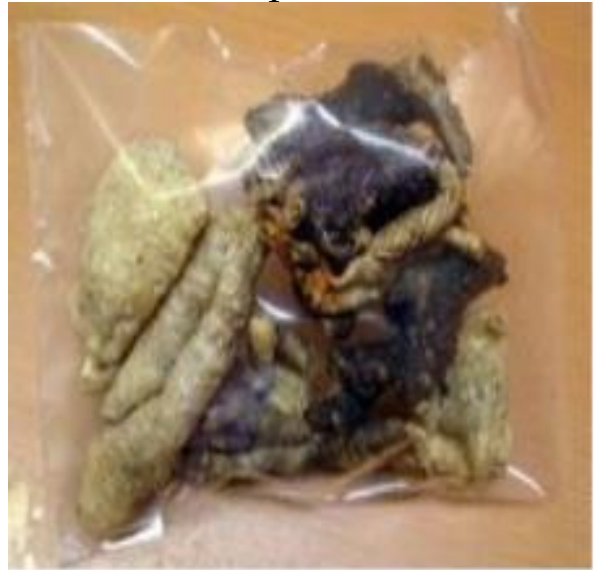

Gambar 6 Kemasan Sederhana Kulit Ikan Pari Menurut Indraswari (2003) beberapa faktor yang dapat mempengaruhi kualitas kerupuk kulit ikan antara lain:

Kerupuk Kulit Ikan Pari Sebagai Alternatif Peningkatan Pendapatan

\section{Kenampak}

Meliputi kondisi fisik, keseragaman (uniform) bentuk dan ukuran serta pengemasan. Pada umumnya kondisi fisik kerupuk ikan kurang menarik bila masih ditemukan adanya sisik ikan dalam jumlah yang cukup banyak. Hal ini menunjukkan proses pengolahan ikan yang kurang baik dan kurang hygienis. Demikian pula bentuk yang kurang seragam memberikan kesan murah, oleh karena itu harns diupayakan keseragaman bentuk dan ukuran supaya kelihatan menarik. Di samping kerapian pengemasan dan jenis baban pengemas produk kerupuk kulit ikan akan mempengaruhi kenampak dan harga jualnya.

\section{Cita rasa}

Cita rasa yang khas dan lezat akan muncul apabila pada saat pembuatan kerupuk kulit ikan dilakukan penambahan bumbu yang sesuai serta asam matang yang berfungsi untuk menghilangkan bau amis. Akan tetapi, rasa pahit yang telah terlanjur ada pada kulit ikan mentah, meskipun dalam jumlah yang relatif sedikit tetap tidak dapat dihilangkan dan tetap saja mengganggu. Rasa pahit tersebut dapat disebabkan oleh adanya pencemaran empedu atau pencemaran air kapur yang digunakan untuk merendam.

3. Minyak Goreng

Untuk menghindari ketengikan (ransiditas) disarankan untuk menggunakan minyak goreng buatan pabrik yang diproduksi secara modem sehingga lebih awet.

\section{Kadar Air}

Daya tahan (keawetan) kerupuk kulit ikan baik yang disimpan dalam keadaan mentah maupun matang antara lain dipengaruhi oleh kadar air yang terkandung di dalamnya. Di samping itu jenis dan cara pengemasan juga berpengaruh terhadap daya simpannya. Hal-hal lain seperti penggunaan garam dan asam serta bumbu bumbu dalam proses pembuatan kerupuk kulit ikan juga dapat membantu meningkatkan daya tahan (daya simpan) kerupuk kulit ikan tersebut.

Diakhir pelatihan pengolahan kulit ikan pari, pengabdi meminta informasi berkaitan dengan pelatihan, dalam kesimpulan awal informasi dan review tersebut sangatlah antusias dan respon terhadap kegiatan tersebut. Dan dari 
peserta juga ada yang menyarankan untuk membuat inovasi lain seperti membuat abon dari kulit ikan pari.

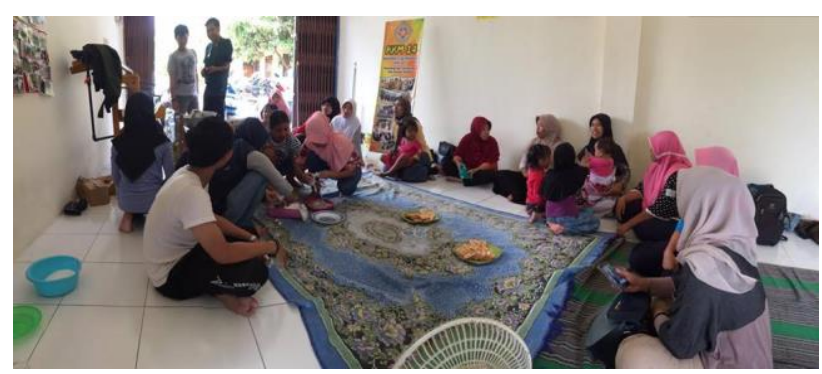

Gambar 7 Review atas Pelatihan Pengolahan

Kulit Ikan Pari

\section{KESIMPULAN DAN SARAN}

\section{Kesimpulan}

Dengan memanfaatkan limbah kulit ikan pari menjadi kerupuk kulit ikan pari berarti telah mengubah sesuatu yang tidak bermanfaat dan tidak bernilai ekonomi menjadi sesuatu produk olahan yang bernilai gizi tinggi serta bernilai ekonomi relatif tinggi dan ramah lingkungan.

\section{Saran}

Untuk pengabdi selanjutnya sebaiknya melakukan inovasi produk lain seperti membuat abon dari kulit ikan pari maupun membuat produk lainnya sesuai dengan keiinginan dari warga,

\section{DAFTAR REFERENSI}

-----1992. Daftar Analisis Bahan Makanan. Jakarta: Laboratorium Kimia LPTD, Fak. Kedokteran UI.

Eddy Pumomo, 2002. Penyamakan Kulit Ikan Pari. Yogyakarta: Penerbit Kanisius.

Hayami, Y. Toshihiko Kawagoe, Yoshinori Marooka and Masdjidin Siregar. 1987. Agricultural Marketing and Processing in Upland Java. A Perspective From A Sunda Village. CGPRT Center. Bogor. 75 p.

Indiaswari, C.H., 2003. Rambak Kulit Ikan. Yogyakarta: Penerbit Kanisius.

Kartono, Kartini. Pengantar Metodologi Riset Sosial. CV Mandar Maju. Bandung. $390 \mathrm{Hal}$.

Rahardi, F., Kristiawati dan Nazarudin. 1996. Agribisnis Perikanan. Penebar Swadaya. Jakarta. 63 Hal. 